\title{
EFEKTIFITAS PERAWATAN METODE KANGURU TERHADAP KUALITAS TIDUR PADA BAYI BERAT LAHIR RENDAH (BBLR) DI RSUD PROVINSI NTB TAHUN 2017
}

\author{
Rima Asqina Fatmawati ${ }^{1}$, Linda Meliati ${ }^{2}$ \\ ${ }^{1}$ Program Studi D IV, Jurusan Kebidanan Poltekkes Mataram Kemenkes RI \\ ${ }^{2}$ Program Studi D IV, Jurusan Kebidanan Poltekkes Mataram Kemenkes RI
}

\begin{abstract}
Abstrack
Latar belakang : Salah satu penyebab kematian bayi di Indonesia adalah BBLR yaitu sebesar 10,2\%. Berdasarkan data dari Dinas Kesehatan Provinsi Nusa Tenggara Barat bulan Agustus 2016 jumlah kasus BBLR yang meninggal sebanyak 149 bayi. Perawatan Metode Kanguru (PMK) sebagai cara yang efektif terutama bagi bayi BBLR dengan meningkatkan hubungan ibu dengan bayi serta membuat bayi lebih nyaman dan dapat tidur lebih tenang. Tidur merupakan momen pematangan organ tubuh dalam proses pertumbuhan perkembangan bayi. Kualitas tidur bayi dengan berat badan lahir rendah (BBLR) dapat dikatakan cukup tidur jika bayi terbangun dalam keadaan segar serta ketika tidur dalam fase tidur tenang. Kualitas tidur bayi dipengaruhi oleh banyak hal baik dari dalam diri atau pun dari luar dirinya.

Metode : Penelitian ini menggunakan rancangan Pre Experimental dengan pendekatan One Group Pretest- Posttest dan dilakukan pada bulan Maret-Mei 2017 di ruang NICU RSUDP NTB. Besar sampel sebanyak 30 responden dan pengumpulan data menggunakan ceklist serta lembar observasi.

Hasil : Penelitian pada perawatan metode kanguru terbanyak pada PMK yang berhasil sebanyaj 26 (86.7\%), kualitas tidur sebelum PMK pada hari ketiga sebanyak 28 (93.3\%) sedangkan kualitas tidur setelah PMK sebanyak 27 (90\%). Hasil penelitian didapatkan bahwa perawatan metode kanguru efektif terhadap kualitas tidur pada BBLR di RSUDP NTB tahun 2017 (analisis uji Fisher p value $=0.031$ ).

Kesimpulan : Perawatan Metode Kanguru efektif terhadap Kualitas Tidur pada BBLR di RSUDP NTB tahun 2017 (p-value 0.031).
\end{abstract}

\section{Kata kunci : Perawatan Metode Kanguru, Kualitas Tidur}

\begin{abstract}
Abstrack
Background: one of the causes of infant mortality in Indonesia was lbw in the amount of $10.2 \%$. Based on data from the Health Department of West Nusa Tenggara In August 2016 the number of cases of low birth weight babies who die as much as 149 . Kangaroo Care (FMD) as an effective means especially for LBW infants with mothers with babies improve relations and make the baby more comfortable and can sleep more restful. Sleep is a moment of maturation of organs in the process of growth of the developing baby. Quality of sleep of infants with low birth weight (LBW) can be quite sleep when the baby woke up fresh as well as sleeping in a phase of quiet sleep. Baby sleep quality is influenced by a lot of good things from within or from outside.

Methods: This study used adesign Pre Experimental approach to one group pretest-posttest and conducted in March-May 2017 in the NICU RSUDP NTB. The sample size of 30 respondents and data collection using the checklist and observation sheet.

Results: The study on the treatment method on FMD kangaroo most successful sebanyaj 26 (86.7\%), quality of sleep before the PMK on the third day were 28 (93.3\%) while the quality of sleep after PMK $27(90 \%)$. The results showed that the kangaroo care method is effective against sleep quality in LBW in the NTB RSUDP 2017 (analysis Fisher's exact test $p$-value $=0.031$ ).
\end{abstract}

Conclusions: Kangaroo Care is effective against Quality in LBW in the NTB RSUDP 2017(p-value 0.031).

\section{Keywords: Care Kangaroo, Sleep Quality}




\section{Pendahuluan}

Hasil survei Depkes RI tahun 2009 menunjukkan Angka kematian bayi di Indonesia masih tergolong tinggi bila di bandingkan dengan negara-negara ASEAN, yaitu 4,6 kali lebih tinggi dari Malaysia, 1,3 kali lebih tinggi dari Filipina, dan 1,8 kali lebih tinggi dari Thailand. ${ }^{1}$

Di Indonesia AKB berdasarkan Survei Dasar Kesehatan Indonesia (SDKI) tahun 2012 mencapai

32 per 1000 KH. Pada Survey Penduduk Antar Sensus (Supas) pada tahun 2015, AKB mencapai 22,23 per 1000 KH. Kejadian BBLR di Indonesia pada tahun 2013 yaitu sebesar 10,2\%.2

Di Indonesia, prevalensi bayi BBLR adalah

5 - 27\%. Perawatan bayi BBLR membutuhkan infrastruktur mahal serta tenaga yang memiliki keahlian tinggi sehingga sering menjadi pengalaman berat bagi keluarga. Perawatan bayi BBLR secara konvensional dengan incubator sangat mahal dan memerlukan tenaga kesehatan terlatih dan fasilitas peralatan memadai, sedangkan di Negara berkembang pendapatan dan sumber daya manusia terbatas dalam perawatan neonatus serta adanya keterbatasan bangsal untuk bayi BBLR. Dengan demikian, perlu adanya intervensi untuk bayi BBLR dalam mengurangi angka kesakitan dan kematian neonatus serta menurunkan biaya perawatan. Hal tersebut sangat penting untuk meningkatkan kesehatan di Negara berkembang. ${ }^{1}$

Di NTB berdasarkan Profil Kesehatan tahun 2014 Angka Kematian Bayi (AKB) masih cukup tinggi jika dibandingkan dengan provinsi lain, dimana pada tahun 2013 Angka Kematian Bayi (AKB) meningkat 72/1000 KH, sedangkan tahun 2014 mengalami penurunan menjadi 57/1000 KH. Komplikasi yang sering terjadi pada bayi diantaranya BBLR sebanyak 289 kasus, asfiksia 103 kasus, pneumonia sebanyak 196 kasus, sepsis 20 kasus, ikterus 16 kasus, dll. ${ }^{3}$

Berdasarkan data awal yang didapatkan dari register BBLR di RSUDP NTB, selama hampir 3 tahun terakhir (2014 sampai September 2016) jumlah kelahiran BBLR sebanyak 1016 dengan 218 kematian selama rawat inap di rumah sakit. Bila dilihat dari data pertahunnya itu tahun 2014, 2015 dan 2016 (sampai September 2016), jumlah kelahiran BBLR masing-masing sebanyak 357, 374, dan 285 bayi dengan kematian selama rawat inap di rumah sakit berturutturut sebanyak 89 bayi,

74 bayi, dan 55 bayi. Cenderung mengalami penurunan kematian BBLR dari tahun 2014 sampai September 2016. Berdasarkan data yang didapatkan dari register BBLR di Ruang NICU RSUDP NTB, selama 2 tahun terakhir (2015 sampai September 2016) jumlah kelahiran BBLR sebanyak 918 bayi dengan 138 kematian selama rawat inap di Ruang NICU. Bila dilihat dari data pertahun yaitu tahun 2015 sebanyak 359 kasus, BBLR yang meninggal sebanyak 85 kasus dan data terakhir tahun 2016 sampai bulan September 2016 sebanyak 379 kasus BBLR yang meninggal sebanyak 53 kasus. $^{4}$

RSUD Provinsi NTB merupakan rumah sakit rujukan dari semua rumah sakit wilayah NTB, dilihat dari data kematian BBLR dari tahun 2014 sampai 2016 justru mengalami penurunan dikarenakan tenaga kesehatan yang sudah terlatih serta standar operasianal prosedur (SOP) juga semakin lengkap, menurut hasil survey yang telah dilakukan RSUD Provinsi NTB diperoleh bahwa sudah dilakukan metode kanguru, namun metode ini dilakukan pada saat bayi sehat, reflek hisap dan menelan sudah kuat serta pada saat bayi akan di pulangkan. Sehingga peneliti mengaharapkan manfaat perawatan metode kanguru bisa mengurangi masalah pada BBLR terutama kualitas tidur. ${ }^{4}$

Efek dari metode kanguru dapat juga dapat memfasilitasi pada bayi BBLR meningkatkan frekuensi dan durasi tidur tenang, sedikit waktu menangis dan tingkat aktivitas yang lebih rendah selama PMK menunjukan hasil yang lebih maksimal sesuai dengan kebutuhan tidurnya. ${ }^{5}$

Berdasarkan penelitian Qori'ila (2010) tentang identifikasi pengaruh perawatan metode 
kanguru terhadap kecemasan ibu dan status bangun tidur pada BBLR di Rumah Sakit Surabaya. Hasil ini didapatkan terdapat pengaruh tentang identifikasi pengaruh perawatan metode kanguru terhadap kecemasan ibu dan status bangun tidur pada BBLR. Hasil yang didapatkan diharapkanakan mampu menjadi dasar yang memperkuat peneliti melakukan penelitian. ${ }^{6}$

Perumusan masalah dalam penelitian ini adalah apakah perawatan metode kanguru efektif terhadap kualitas tidur pada bayi berat lahir rendah (BBLR) Di RSUD Provinsi NTB Tahun 2017? Tujuan penelitian adalah untuk mengetahui efektif itas perawatan metode kanguru terhadap kualitas tidur pada bayi berat lahir rendah (BBLR) Di RSUD Provinsi NTB Tahun 2017

Berdasarkan uraian dari latar belakang di atas penulis tertarik untuk melakukan Metode Kanguru pada pasien yang BBLR sebab pada pasien BBLR sering mengalami masalah tidur.

\section{Metode}

Jenis penelitian ini merupakan penelitian Quasi Experimental dengan pendekatan One Group Pretest-Posttest. Sampel penelitian ini adalah semua BBLR yang dirawat diruang NICU dirawat diruang NICU (level III) RSUD Provinsi NTB pada bulan Maret-Mei 2017. Pengambilan sampel pada penelitian ini menggunakan teknik Purposive Sampling dengan kriteria Inklusi dan Eksklusi. Kriteria inklusi dalam penelitian ini adalah : Bayi Berat Lahir Rendah (berat badan 1800-2400 gram), BBLR yang berusia 0-28 hari saat pelaksanaan penelitian, BBLR semua keadaan patologis sudah teratasi, BBLR mampu menghisap, menelan dan sudah baik dan BBLR dengan usia aterm dan preterm. Kriteria eksklusi sampel dalam penelitian ini adalah : BBLR dalam keadaan sakit, BBLR yang mendapatkan PMK kurang dari 2 jam, Orang tua BBLR yang berhenti melakukan PMK. Analisis data dalam penelitian ini menggunakan uji Fisher.

\section{Hasil}

Tabel 1. Distribusi Frekuensi Perawatan Metode Kanguru pada BBLR di RSUDP Tahun 2017

\begin{tabular}{cccc}
\hline No & $\begin{array}{c}\text { Perawatan } \\
\text { Metode } \\
\text { Kanguru }\end{array}$ & (n) & $(\boldsymbol{\%})$ \\
\hline 1 & PMK Berhasil & 26 & 86.7 \\
\hline 2 & PMK Tidak. Berhasil & 4 & 13.3 \\
\hline & Total & 30 & 100 \\
\hline
\end{tabular}

Berdasarkan Tabel 1 didapatkan bahwa perawatan metode kanguru berhasil sebanyak $26(86.7 \%)$ lebih banyak dibandingkan dengan perawatan metode kangguru tidak berhasil sebanyak 4 (13.3\%). 
Tabel 2. Distribusi Frekuensi Kualitas Tidur BBLR Pretest Perawatan Metode Kanguru di ruang NICU RSUDP NTB tahun 2017

\begin{tabular}{|c|c|c|c|c|c|c|c|}
\hline & \multirow{2}{*}{$\begin{array}{c}\text { Status Tidur } \\
\mathrm{n}\end{array}$} & \multicolumn{2}{|c|}{ Hari 1 Pretest } & \multicolumn{2}{|c|}{ Hari 2 Pretest } & \multicolumn{2}{|c|}{ Hari 3 Pretest } \\
\hline & & & $\%$ & $\mathrm{n}$ & $\%$ & $\mathrm{n}$ & $\%$ \\
\hline 1 & Tidur berkualitas & 5 & $16.0_{7}$ & 19 & 63.3 & 28 & 93.3 \\
\hline 2 & $\begin{array}{c}\text { Tidur tidak } \\
\text { berkualitas }\end{array}$ & 25 & 83.3 & 11 & 37.7 & 2 & 6.7 \\
\hline & Total & 30 & 100 & 30 & 100 & 30 & 100 \\
\hline
\end{tabular}
dengan status tidur berkualitas sebanyak pada hari ketiga 28 (93.3\%). Sedangkan untuk status tidur tidak berkualitas paling sedikit pada hari ketiga $2(6.7 \%)$.

Tabel 3. Distribusi Frekuensi Kualitas Tidur Prosttest Perawatan Metode Kanguru di ruang NICU RSUDP NTB tahun 2017

\begin{tabular}{cccccccc}
\hline $\begin{array}{c}\mathrm{N} \\
\mathrm{O}\end{array}$ & Status Tidur & \multicolumn{2}{c}{ Hari 1 Prosttest } & \multicolumn{2}{c}{ Hari 2 Prosttest } & \multicolumn{2}{c}{ Hari 3 } \\
Prosttest
\end{tabular}

Berdasarkan Tabel 3 diperoleh presentase kualitas tidur setelah PMK pada BBLR dengan status tidur berkualitas terbanyak hari ketiga yaitu 27 (90\%). Sedangankan status tidur tidak berkualitas paling sedikit pada hari ketiga sebanyak 3 $(10 \%)$.

Tabel 4. Efektifitas Perawatan Metode Kanguru terhadap Kualitas Tidur pada BBLR di RSUDP NTB Tahun 2017

\begin{tabular}{|c|c|c|c|c|c|c|c|c|}
\hline \multirow{3}{*}{$\begin{array}{l}\text { Perawatan } \\
\text { Metode } \\
\text { Kangguru }\end{array}$} & \multicolumn{4}{|c|}{ Kualitas Tidur } & \multirow{2}{*}{\multicolumn{2}{|c|}{ Total }} & \multirow[t]{3}{*}{ OR } & \multirow[t]{2}{*}{$P$-value } \\
\hline & \multicolumn{2}{|c|}{$\begin{array}{c}\text { Tidak } \\
\text { Berkualitas }\end{array}$} & \multicolumn{2}{|c|}{ Berkualitas } & & & & \\
\hline & $\mathrm{n}$ & $\%$ & $\mathrm{n}$ & $\%$ & $\mathrm{n}$ & $\%$ & & \\
\hline Berhasil & 22 & 84.6 & 4 & 15.4 & 26 & 100 & 16.5 & \\
\hline Tidak berhasil & 1 & 25 & 3 & 75.0 & 4 & 100 & 201.3 & 0.031 \\
\hline Jumlah & 23 & 76.7 & 7 & 23.3 & 100 & 100 & & \\
\hline
\end{tabular}

Berdasarkan Tabel 4 efektifitas perawatan metode kanguru dengan kualitas tidur diperoleh sebanyak $22(84.6 \%)$ perawatan metode kanguru yang berhasil mengalami tidur berkualitas sedangkan perawatan metode kanguru yang tidak berhasil ada 1 (25\%) yang tidur berkualitas. Hasil uji statistik menggunakan uji Fisher diperoleh $\mathrm{p}$ value $=0.031$ atau $\mathrm{p}<\alpha=0.05$ artinya Perawatan Metode Kanguru efektif terhadap kualitas tidur pada 
BBLR di RSUDP NTB tahun 2017. Dari hasil analisis diperoleh nilai OR=16.5 artinya PMK yang berhasil mempunyai peluang 16.5 kali untuk tidur berkualitas dibandingkan dengan PMK yang tidak berhasil.

\section{Pembahasan}

\section{A.Perawatan Metode Kanguru pada Bayi Berat Lahir Rendah (BBLR)}

Berdasarkan hasil yang telah dilakukan didapatkan perawatan metode kanguru berhasil sebanyak $26(86.7 \%)$ dan perawatan metode kanguru tidak berhasil sebanyak 4 (13.3\%). Keberhasilan PMK juga berdasarkan data ratarata responden memiliki pendidikan terakhir SMA 50\%. Hal ini sesuai pendapat Yahya, A (2005) mengatakan bahwa semakin tinggi pendidikan yang dimiliki seseorang, maka kecenderungan tingkat pengetahuannya semakin tinggi. Selain dari tingkat pengetahuan dipengaruhi juga oleh pekerjaan. Ibu responden sebagian besar tidak bekerja atau ibu rumah tangga sebanyak 24 orang (80\%). ${ }^{10}$ Hal ini menentukan keberhasilan ibu dalam melakukan PMK dirumah sakit atau pun di rumah karena ibu lebih patuh dalam melakukan PMK dan lebih mudah menyusui bayinya secara ekslusif.

Pada saat pelaksanaan PMK, adanya kontak kulit antara ibu dengan bayinya merupakan stimulus yang akan dibawa ke otak. Selanjutnya stimulus ini akan memicu pelepasan oksitosin yang akan berdampak positif terhadap emosional ibu.

Ibu yang mendapatkan PMK memperlihatkan emosi yang lebih stabil dibandingkan dengan ibu yang tidak mendapat PMK. Ibu yang melakukan PMK secara bermakna dapat merasakan stresnya berkurang, meningkatkan rasa percaya diri, dan merasakan kepuasan tersendiri karena telah melakuan sesuatu yang positif untuk bayinya yang lahir prematur dibandingkan dengan ibu yang tidak melakukan PMK. ${ }^{11}$

Penelitian lainnya menyebutkan bahwa ibu yang melakukan PMK merasa lebih percaya diri dalam merawat bayinya dibandingkan dengan ibu yang tidak melakukan PMK. PMK juga meningkatkan kedekatan ibu dan bayinya, mengurangi perasaan stress pada ibu sebagaimana pada bayi, serta membuat ibu dan bayi lebih tenang dan rileks. Semakin dini metode kanguru diterapkan maka hasilnya semakin baik. ${ }^{12}$

\section{B. Kualitas Tidur BBLR Sebelum Perawatan Metode Kanguru}

Kualitas tidur sebelum perawatan metode kanguru pada BBLR dengan status tidur berkualitas hari pertama sampai hari ketiga terus meningkat dari hari kehari, hari pertama sebanyak 5 (16.7\%), hari kedua 19 (63.3\%), dan hari ketiga 28 (93.3\%). Sedangkan untuk status tidur tidak berkualitas mengalami penurunan setiap hari, hari pertama sebanyak 25 (83.3\%), hari kedua 11

(37.7\%) dan hari ketiga 2 (6.7\%). Pada penelitian ini kualitas tidur dengan tidur berkualitas rata-rata mengalami status mengantuk dan tidur aktif.

Menurut penelitian Lailaningsih, S, (2016) di Pekalongan mengatakan kualitas tidur yang tidak diberikan PMK pada hari pertama $60 \%$ bayi terjaga aktif, hari kedua $70 \%$ bayi tidur aktif, dan hari ketiga $60 \%$ bayi tidur aktif. Hal ini menunjukkan kualitas tidur bayi yang tidak diberikan PMK selama 3 hari mengalami fase tidur aktif. ${ }^{13}$

Kualitas tidur bayi BBLR sebelum diberikan PMK menunjukan sebagian sering mengalami tidur aktif yang ditandai dengan adanya gerakan ektermitas atas bawah, 
menggeliat, perubahan ekspresi wajah, penutupan mata dengan gerakan bola mata dan terdapat gerakan terkejut saat terdapat stimulus atau kebisingan lingkungan sehingga terkadang menyebabkan bayi menjadi stress. Stress mempengaruhi fungsi hipotalamus yang berpengaruh buruk terhadap pertumbuhan, produksi panas dan mekanisme neurologis. Intervensi yang dirancang untuk mengurangi stress pada bayi menghasilkan perbaikan dalam tingkah laku tidur dan pertumbuhan. ${ }^{14}$

\section{C.Kualitas Tidur BBLR Setelah Perawatan Metode Kanguru}

Kualitas tidur setelah perawatan metode kanguru pada BBLR dengan status tidur berkualitas hari pertama sebanyak 23 (76.6\%), hari kedua 26 (86.7\%) dan ketiga sebanyak 27 (90\%). Sedangankan status tidur tidak berkualitas hari pertama sebanyak 7 (23.3\%), harikedua 4 (13.3\%) dan hari ketiga sebanyak 3 (10\%). Pada penelitian ini rata-rata kualitas tidur dengan tidur berkualitas pada bayi mengalami status tidur aktif dan tidur tenang.

Berdasarkan penelitian Lailaningsih, S, (2016) di Pekalongan mengatakan kualitas tidur yang diberikan PMK pada hari pertama $60 \%$ bayi tidur aktif, hari kedua $70 \%$ bayi tidur tenang dan hari ketiga $70 \%$ bayi tidur tenang. Hal ini menunjukkan kualitas tidur bayi yang diberikan PMK selama 3 hari mengalami fase tidur tenang. ${ }^{13}$

Menurut Saidah, dkk (2011) bayi BBLR yang mempunyai pertumbuhan dan perkembangan yang optimal akan mampu mengontrol stimulus yang datang padanya dengan merubah berbagai status bangun tidurnya. Sebagian besar bayi mengalami status tidur aktif dimana bayi tidak tidur dengan nyenyak pada tahap ini pertumbuhan dan perkembangan kurang optimal dibandingkan dengan bayi aterm yang mampu menghabiskan sebagian besar waktunya dengan tidur tenang. Tidur tenang merupakan fase tidur yang mampu memberikan fasilitasi pertumbuhan dan perkembangan yang optimal. ${ }^{15}$

Dalam kondisi PMK ini akan memberikan manfaat terhadap bayi lebih tenang dan rileks saat tidur, berbaring tenang, dan napasnya teratur sebagai akibat kontak langsung dengan orang tuanya. 16

\section{Efektifitas Perawatan Metode Kanguru terhadap Kualitas Tidur pada BBLR}

Perawatan metode kanguru dengan kualitas tidur diperoleh sebanyak 22 (84.6\%) perawatan metode kanguru yang berhasil mengalami tidur berkualitas dan perawatan metode kanguru yang tidak berhasil ada $1(25.0 \%)$ yang tidur berkualitas. Sedangkan untuk perawatan metode kanguru yang berhasil mengalami tidur tidak berkualitas sebanyak

$4(15.4 \%)$ dan perawatan metode kanguru yang tidak berhasil ada $3(75.0 \%)$ yang tidur tidak berkualitas.

Hasil uji statistik menggunakan uji Fisher diperoleh $\mathrm{p}$ value $=0.031$ atau $\mathrm{p}<\alpha=0.05$ yang artinya terdapat Efektifitas Perawatan Metode Kanguru terhadap Kualitas Tidur pada BBLR di RSUDP NTB tahun 2017. Dari hasil analisis diperoleh pula nilai OR=16.5 artinya perawatan metode kanguru yang berhasil mempunyai peluang

16.5 kali untuk tidur berkualitas dibandingkan dengan perawatan metode kanguru yang tidak berhasil.

Status bangun tidur mempengaruhi kemampuan bayi untuk merespon stimulus yang datang padanya. Kemampuan bayi dalam merespon stimulus ini terlihat dari perubahan status bangun- tidurnya. Bayi yang mempunyai masalah neurologis menunjukkan pola tidur 
yang abnormal. Bangun dan tidur mempengaruhi perkembangan otak dan kemampuan belajar yang berlanjut setelah bayi pulang dari rumah sakit. ${ }^{17}$

Analisis peneliti, bayi yang mempunyai pertumbuhan dan perkembangan yang optimal akan mampu mengontrol stimulus yang datang padanya dengan merubah berbagai status bangun-tidurnya. Sebagian besar bayi mengalami status tidur aktif dimana bayi tidak tidur dengan nyenyak. Pada tahap ini pertumbuhan dan perkembangan kurang optimal dibandingkan dengan bayi aterm yang mampu menghabiskan sebagian besar waktunya dengan tidur tenang. Tidur tenang merupakan fase tidur yang mampu memberikan fasilitasi pertumbuhan dan perkembangan yang optimal. Oleh karenanya berbagai metode untuk memfasilitasi fase tidur bagi bayi merupakan hal yang penting. Hal ini sesuai dengan penelitian Shiau (2005) yang menyatakan bahwa PMK mempengaruhi penurunan hormon stress pada bayi dan ibu.

\section{Kesimpulan}

1. Perawatan metode kanguru terbanyak pada PMK yang berhasil sebanyak $26(86.7 \%)$

2. Kualitas tidur sebelum perawatan metode kanguru pada BBLR dengan status tidur berkualitas terbanyak pada hari ketiga sebanyak 28 (93.3\%).

3. Kualitas tidur setelah perawatan metode kanguru pada BBLR dengan status tidur berkualitas terbanyak hari ketiga sebanyak 27 (90\%).

4. Perawatan metode kanguru efektif terhadap kualitas tidur pada BBLR di RSUD Provinsi NTB tahun 2017 (P-Value 0.031).

\section{Saran}

1. Bagi rumah sakit telah disediakan ruangan khusus (Perawatan Kanguru) untuk perawatan metode kanguru namun ruangan tersebut jarang digunakan, karena sebagian besar orang tua melakukan PMK diruangan perawatan, sebaiknya seluruh pasien yang akan diberikan PMK dilakukan diruangan perawatan kanguru sehingga orang tua khususnya ibu dan bayi dapat leluasa melakukan PMK dan dalam pemberian susu.

2. Bagi tenaga kesehatan khususnya yang berada diruang NICU harus lebih meningkatkan program follow-up pasien-pasien yang sudah pulang secara berkala tidak hanya satu hari setelah pulang, Follow-up bisa dilakukan pada hari ke-2 atau seminggu sehingga bayi dan ibu tetap terpantau.

\section{Daftar Pustaka}

1. Departemen Kesehatan Republik Indonesia. (2009). Profil Kesehatan Indonesia 2008. Jakarta. (http://www.depkes.go.id/downloads/publikasi /profil\%kesehatan\%20Indonesia.pdf.

2. 2013, Riset Kesehatan Dasar Tahun 2013, Jakarta (www.depkes.go.id/resources/download/gener al/Hasil\%20Riskesdas\%202013.pdf)

3. Dinkes, R.I. 2015. Profil Kesehatan Propinsi NTB 2015. NTB

4. RSUD Provinsi NTB. (2016). Data Dalam Angka Register NICU. Mataram

5. Hocken berry, M.J., \& Wilson, D. (2007). Wong's Nursing Care Of Infants and Children. Missouri: Mosby, Inc., an affiliate of Elsevier Inc. 
6. Arora, S. (2008). Kangoroo Mother Care. Nursing Journal of India, 99 (11) : 248-250. (http://www.proquest.umi.com)

7. Tessier et al. (2004). Kangoroo Mother Care and Bonding Hypothesis. (http://www.pediatrics.org/cgi/content/full/102 /2/e17)

8. Lailaningsih, S. (2016). Pengaruh Perawatan Metode Kanguru Terhadap Kualitas Tidur Bayi Berat Badan Lahir Rendah (BBLR) di RSUD Kraton Kabupaten Pekalongan dan RSUD Kabupaten Batang. Pekalongan. STIKES MUHAMMADIYAH.

9. Wong, et al. (2009). Buku Ajar Keperawatan Pediatrik ed.6 Volume 1. Jakarta: EGC

10. Saidah, Q., Rustina, Y \&Nurhaeni N. 2011,'Penurunan Kecemasan Ibu dan Perbaikan Status BangunTidur BBLR Melalui Perawatan Metode Kanguru', Jurnal Keperawatan Indonesia, vol. 14, no. 3, h. 197.

11. Rini \& Nuri (2006). Gangguan Tidur pada Anak Usia Dibawah Tiga Tahun di Lima Kota Indonesia. Jurnal Sari Pediatri, Volume 7, Nomor 4, Maret 2006.

12. Sekartini,R. \& Adi, N.P. 2006, 'Gangguan Tidur Pada Anak Usia di Bawah 3 tahun di Lima Kota di Indonesia ', Sari Pediatri, vol.7, No.4, hh.188-183

13. Shiau, S.H. (2005). Randomized Controlled Trial of Kangoroo Care With Fullterm Infants: Effects on Maternal Anxiety, Breastmilk Maturation, Breast Engorgement, and Breastfeeding int/neoreviews;8/2/e55).

Status. (http://neoreviews.aappublications.org/cgi/repr 